\title{
Perancangan Aplikasi Media Pembelajaran Interaktif Pengenalan Anatomi Tubuh Manusia Berbasis Android
}

Designing Interactive Learning Media Applications for Introduction to the Anatomy of the Human Body Based on Android

\author{
Elly Veronika Sihite ${ }^{l}$, Rika Rosnelly ${ }^{2 *}$ \\ ${ }^{1}$ Program Informatika,Fakultas Teknik dan Ilmu Komputer, Universitas Potensi Utama \\ ${ }^{2 *}$ Program studi Ilmu Komputer, Fakultas Teknik dan Ilmu Komputer, Universitas Potensi Utama \\ Jl.K.L. Yos Sudarso KM 6.5 Tanjung Mulia-Medan \\ E-mail: Ellyveronika06@gmail.com ${ }^{1}$, rikarosnelly@gmail.com ${ }^{2 *}$ \\ *Corresponding author
}

\begin{abstract}
ABSTRAK
Penggunaan media pembelajaran interaktif dalam proses belajar-mengajar di sekolah dapat membangkitkan keinginan dan minat yang baru, dan rangsangan kegiatan belajar dan bahkan membawa pengaruh-pengaruh psikologis. Media pembelajaran adalah komponen sumber belajar atau wahana fisik yang mengandung materi intruksional dilingkungan siswa yang dapat merangsang siswa untuk belajar. Minimnya pengulangan pelajaran yang dilakukan oleh orang tua dirumah dapat membuat anak-anak akan cepat lupa dengan pelajaran yang ia dapat. Dengan adanya program tersebut dapat membantu anak-anak untuk mengulang pelajaran kapan saja, dan membantu para orang tua untuk mengajari anak mereka dirumah. Selain itu dengan adanya media pembelajaran interaktif tersebut juga dapat membuat anak-anak merasa bahwa mereka tidak hanya sedang belajar, tetapi juga sedang bermain. Aplikasi pembelajaran interaktif mengenal organ tubuh manusia ini dirancang dengan menggunakan aplikasi Adobe Flash. Output yang dihasilkan dari rancangan media pembelajaran ini berupa aplikasi media pembelajaran interaktif mengenal organ tubuh manusia yang di dalamnya terdapat gambar organ tubuh beserta fungsinya.
\end{abstract}

Kata Kunci : Pembelajaran Interaktif, Media Pembelajaran, Anatomi Tubuh

\section{ABSTRACT}

The use of interactive learning media in the teaching-learning process in schools can generate new desires and interests, and stimulate learning activities and even bring psychological influences. Learning media are components of learning resources or physical vehicles that contain instructional material in the student environment that can stimulate students to learn. the lack of repetition of lessons done by parents at home can make children will quickly forget the lessons they can. With this program can help children to repeat the lesson at any time, and help parents to teach their children at home. In addition, the presence of interactive learning media can also make children feel that they are not only learning, but also playing. This interactive learning application to recognize human organs is designed using the Adobe Flash application. The output generated from the design of learning media in the form of interactive learning media applications recognize human organs in which there are pictures of organs and their functions.

Keywords: Inactive Learning, Learning Media, Body Anatomy.

\section{PENDAHULUAN}

Anatomi atau ilmu urai mepelajari susunan tubuh dan hubungan bagian - bagiannya satu sama lain. Anatomi regional mempelajari letak geografis bagian tubuh. Setiap region atau daerah, misalnya lengan, tungkai, kepala, dada, dan seterusnya ternyata terdiri atas sejumlah struktur atau 
susunan yang umum didapati pada semua region. Struktur itu meliputi tulang otot, saraf, pembuluh darah dan seterusnya. Dengan dasar penelaahan seperti itu dijumpai di sistem jaringan yang berbeda-beda. Semua itu dikelompokkan bersama dan diterangkan dalam bab anatomi sistematik.

Fisiologi mempelajari fungsi atau kerja tubuh manusia dalam keadaan normal. Ilmu ini sangat erat kaitannya dengan pengetahuan tentang semua makhluk hidup yang tercakup dalam pelajaran biologi. Selain itu, ilmu ini juga berhubungan erat dengan tugas ahli sitologis yang mempelajari [1].

Istilah yang digunakan dalam anatomi. Banyak bagian tubuh yang terletak simetri, misalnya anggota gerak mata dan telinga, paru - paru, serta ginjal. Namun, banyak juga terdapat asimetrispada susunan tubuh. Limfe terletak disebelah kanan, pankreas terletak disebelah kiri sebagian dan disebelah kanan sebagian [2].

Anatomi tubuh manusia merupakan satu pilar utama dalam pendidikan kesehatan. Beberapa jurusan kesehatan diantaranya yakni: kedokteran, keperawatan, farmasi, kebidanan, kesehatan masyarakat. Masing-masing jurusan tersebut mempelajari anatomi tubuh manusia. Mata kuliah anatomi disetiap jurusan kesehatan secara umum pokok pembahasannya sama, dipelajari pada saat semester awal.

Materi-materi yang diajarkan mempelajari tentang struktur yang menyusun tubuh manusia dan fungsi kerja dari setiap struktur tubuh tersebut. Dalam tataran awal materi diajarkan pengertian anatomi, berbagai istilah yang berkaitan dengan anatomi serta sejarah anatomi tubuh manusia. Komposisi dan komponen manusia mengajarkan tentang struktur terkecil bagian tubuh pada tingkat sel dan jaringan beserta fungsi dari tiap-tiap organ sel.

Unified Modelling Language (UML) merupakan satu kumpulan konvensi pemodelan yang digunakan untuk menentukan atau menggambarkan sebuah sistem software yang terkait dengan objek. UML merupakan salah satu alat bantu yang sangat handal dalam bidang pengembangan sistem berorientasi objek karena UML menyediakan Bahasa pemodelan visual yang memungkinkan pengembang sistem membuat blue print atas visinya dalam bentuk yang baku. UML berfungsi sebagai jembatan dalam mengkomunikasikan beberapa aspek dalam sistem melalui jumlah elemen grafis yang bisa dikombinasikan menjadi Unified Modeling Language (UML) biasa digunakan untuk [3]:

a. Menggambarkan batasan sitem dan fungsi - fungsi sistem secara umum, dibuat dengan use case dan actor.

b. Menggambarkan kegiatan atau proses bisnis yang dilaksanakan secara umum, dibuat dengan interaction diagrams.

c. Menggambarkan representasi struktur static sebuah sistem dalam betuk class diagrams.

d. Membuat model behavior "yang menggambarkan kebiasaan atau sifat sebuah sistem" dengan state transition diagrams.

e. Menyatakan arsitektur implementasi fisik menggunakan component and development.

f. Menyampaikan atau memperluas fungsionality dengan stereotypes.

Keseluruhan adalah proses pembandingan antara kompetisi individu dengan kompetisi jabatan maka akan diketahui perbedaanya (disebut juga gap), semakin kecil gap yang dihasilkan maka bobot nilainya akan menjadi lebih besar yang berarti akan memiliki peluang yang lebih besar untuk diterima. Hasil Jurnal adalah menerapkan metode Profile Matching sebagai metode pada Sistem Pengambilan Keputusan Penerimaan Staff Pengajar di Yayasan Islamic Center Medan yang dirancang memiliki kesesuaian sistem dengan proses yang dilakukan secara manual dengan nilai keakuratan $100 \%$ [4].

Kompetensi individu dengan kompetensi jabatan sehingga akan diketahui perbedaan kompetensinya. Sejauh ini Profile Maching digunakan untuk seleksi karyawan berprestasi, perencanaan karir, Mutasi karyawan, kenaikan jabatan dan sebagainya yang berhubungan dengan kemampuan personal. Hasil jurnal adalah perhitungan dengan menggunakan metode Profile Matching berdasarkan data standar yang terdapat pada SSB Sriwijaya, merupakan parameter untuk menentukan kelayakan seorang Asisten Pelatih Sepak Bola. Dengan hasil Pengujian ke sistem mencapai tingkat $100 \%$ keakurasiannya [5].

Sebuah mekanisme untuk pengambilan keputusan dengan mengasumsikan bahwa tingkat variabel prediktor yang ideal harus dimiliki oleh calon anggota baru, bukannya tingkat minimal yang harus dipenuhi atau dilewati. Dari jurnal diketahui hasil akhir antara perhitungan analisa 
manual dengan perhitungan analisa Aplikasi DSS Penseleksian calon Anggota Baru BEM pada Universitas Potensi Utama, memiliki hasil yang akurasi manual dengan software yang dibangun mencapai keakurasian 100\% sehingga dengan menggunakan metode Profile Matching akan lebih mempermudah menyelesaikan masalah [6].

Dalam memprediksi Tingginya Pemakaian Listrik, Hasil Jurnal yaitu Penerapan Metode Fuzzy Mamdani dipilih karena tingkat kecocokannya dalam memprediksi pemakaian listrik lebih baik dibandingkan sugeno berdasarkan luar rumah, tegangan dan perlengkapan. Pengujian yang dilakukan dengan menggunakan nilai luas rumah, perlengkapan yang digunakan dan tegangan akan menjadi besar pemakaian listriknya [7].

Pengembang memiliki beberapa pilihan ketika membuat aplikasi yang berbasis Android. Kebanyakan pengembang menggunakan Eclipse yang tersedia secara bebas untuk merancang dan mengembangkan aplikasi Android. Eclipse adalah IDE yang paling popular untuk pengembangan Android, karena memiliki Android plug-in yang tersedia untuk memfasilitasi pengembangan Android [8].

Kualitas sumber daya manusia (SDM) merupakan salah satu faktor untuk meningkatkan Produktivitas kinerja suatu organisasi atau instansi. PT. Mas Putih Belitung merupakan salah satu perusahaan terkemuka yang bergerak dalam bidang industri. Terdapat 12 orang kepala bagian pada departemen produksi yang bertanggung jawab dan berwenang dalam kelancaran produksi maka oleh karena itu Penerpan ANP dilakukan dalam penelitian untuk melihat hasil penilaian kinerja pada setiap kepala bagian produksi tersebut, sehingga hal ini bermanfaat untuk acuan dalam melakukan evaluasi kompetensi pada setiap kepala bagian departement produksi [9].

Augmented Reality dapat dikatakan sebagai sebuah teknologi yang relatif baru dan masih terus dikembangkan sampai saat ini. Dengan menggunakan konsep penggabungan aspek dunia nyata dengan aspek virtual yang yang saling termediasi, dapat menciptakan suatu kesan bahwa dimensi aspek nyata kita akan diperkaya dengan penambahan bentuk benda maya tiga dimensi. Augmented Reality ini memiliki kelebihan tampilan visual yang menarik, yang mampu memunculkan objek 3 dimensi disertai dengan animasi yang seolah-olah berada pada lingkungan nyata juga dapat dimungkinkan pengguna melakukan interaksi 3 Dimensi secara langsung yang dapat memberikan kesan tersendiri pada pengguna [10].

Pemanfaatan teknologi smartphone dapat membantu pelajar dan orang dewasa dalam mempelajari suatu bahasa asing dengan aplikasi berbasis sistem Android. Dalam penelitian ini dirancang aplikasi media pembelajaran huruf dan kosakata hiragana bahasa Jepang menggunakan Android. Perancangan program ini menggunakan Android Studio. Hasil penelitian berupa aplikasi belajar bahasa Jepang yang menyediakan materi pengenalan huruf Hiragana dan kosakata mengguanakan audio dan bank soal [11].

\section{METODE PENELITIAN}

\section{1. $\quad$ Studi Pustaka (Library Reasearch)}

Pada studi ini penulis mengutip dari beberapa bacaan yang berkaitan dengan perancangan aplikasi media pembelajaran interaktif pengenalan anatomi tubuh manusia berbasis android. Pengutipan yang dilakukan dapat berupa teori ataupun beberapa pendapat dari beberapa buku bacaan ataupun buku diktat yang dipergunakan selama kuliah. Hal ini dimaksudkan untuk memberikan landasan teori yang kuat melalui buku-buku atau literatur yang penulis gunakan.

2. Pengumpulan Bahan

Mengumpulkan data dan informasi yang diperlukan dalam pembangunan aplikasi pembelajaran.

\section{HASIL DAN PEMBAHASAN}

Pengaruh handphone saat ini sangat besar bagi masyarakat dan juga untuk dunia pendidikan sangatlah cepat dengan adanya kemajuan teknologi handphone di masa sekarang ini banyak orang yang menggunakan handphone untuk belajar termasuk juga mahasiswa kesehatan, untuk itu penulis membuat aplikasi sebagai media bantu mahasiswa untuk belajar tentang anatomi menggunakan android, agar mempermudah mahasiswa belajar saat tidak membawa buku. 
Use Case Diagram merupakan model diagram UML (Unified Modelling Language) yang digunakan untuk menggambarkan requirement fungsional yang diharapkan dari sebuah sistem, proses sistem yang akan dirancang digambarkan dengan use case diagram yang terdapat pada Gambar 1.

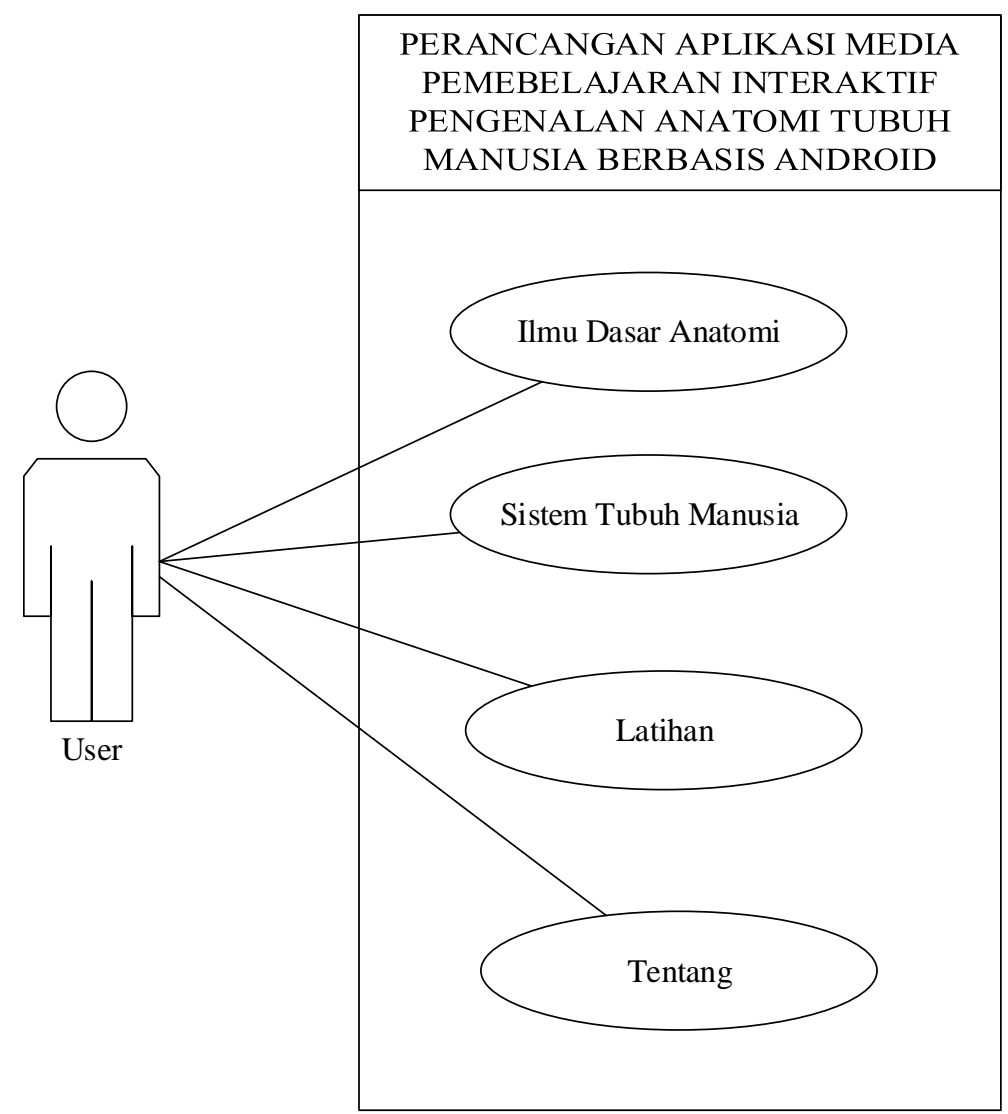

Gambar 1. Use Case Diagram

Storyboard adalah kolom cerita yang dituangkan dalam beberapa bagian, dengan tujuan agar animasi yang akan dirancang nantinya tidak lari dari alur yang telah ditetapkan. Tabel 1. berikut adalah storyboard dari Perancangan Aplikasi Media Pembelajaran Untuk Anak Usia Dini Berbasis Android. 
Tabel 1. Storyboard Anatomi Tubuh Manusia

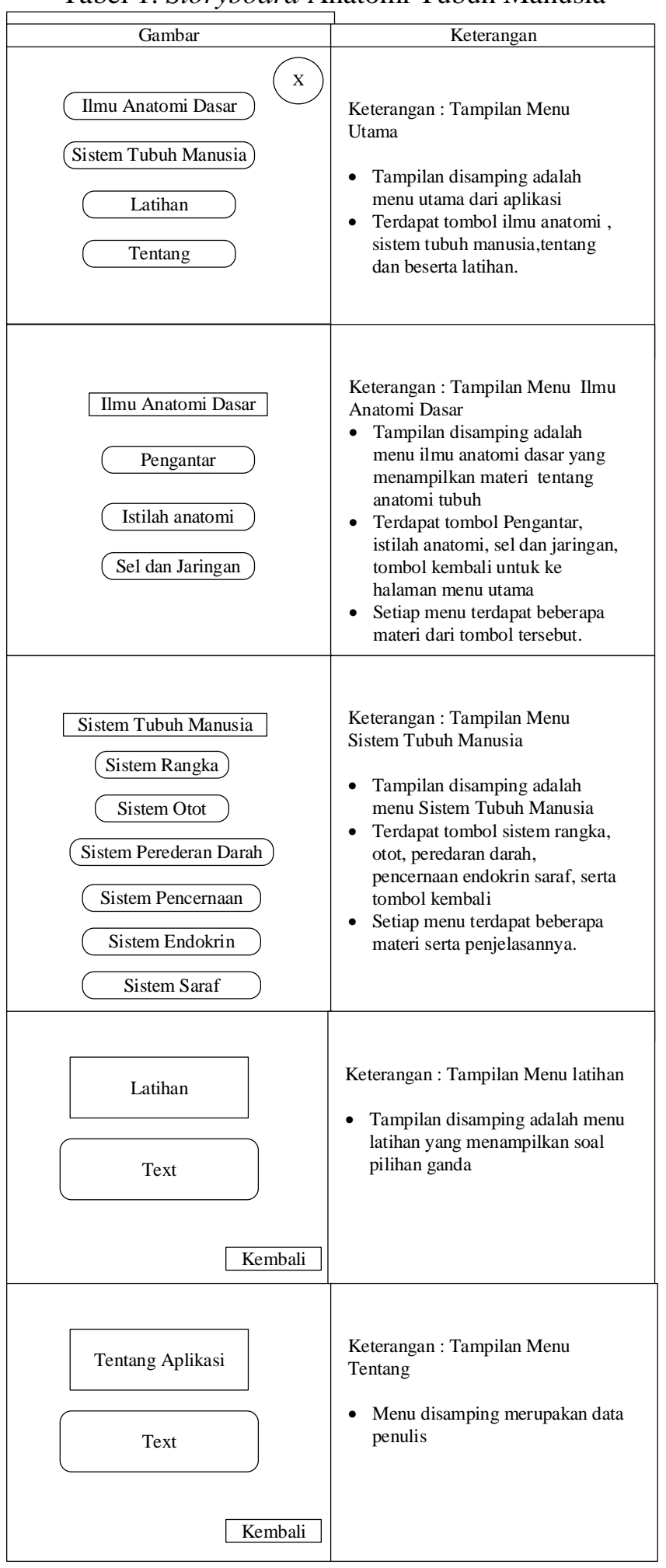

Tabel.1. menunjukkan halaman utama, selanjutnya akan menampilkan menu utama, halaman menu utama menampilkan menu anatomi tubuh,diagnosa penyakit,cara mencegah penyakit. Dalam setiap menu akan menampilkan materi belajar masing - masing. 
Adapun sequence diagram user akan memilih halaman menu Ilmu Anatomi Dasar dapat dilihat pada Gambar 2.

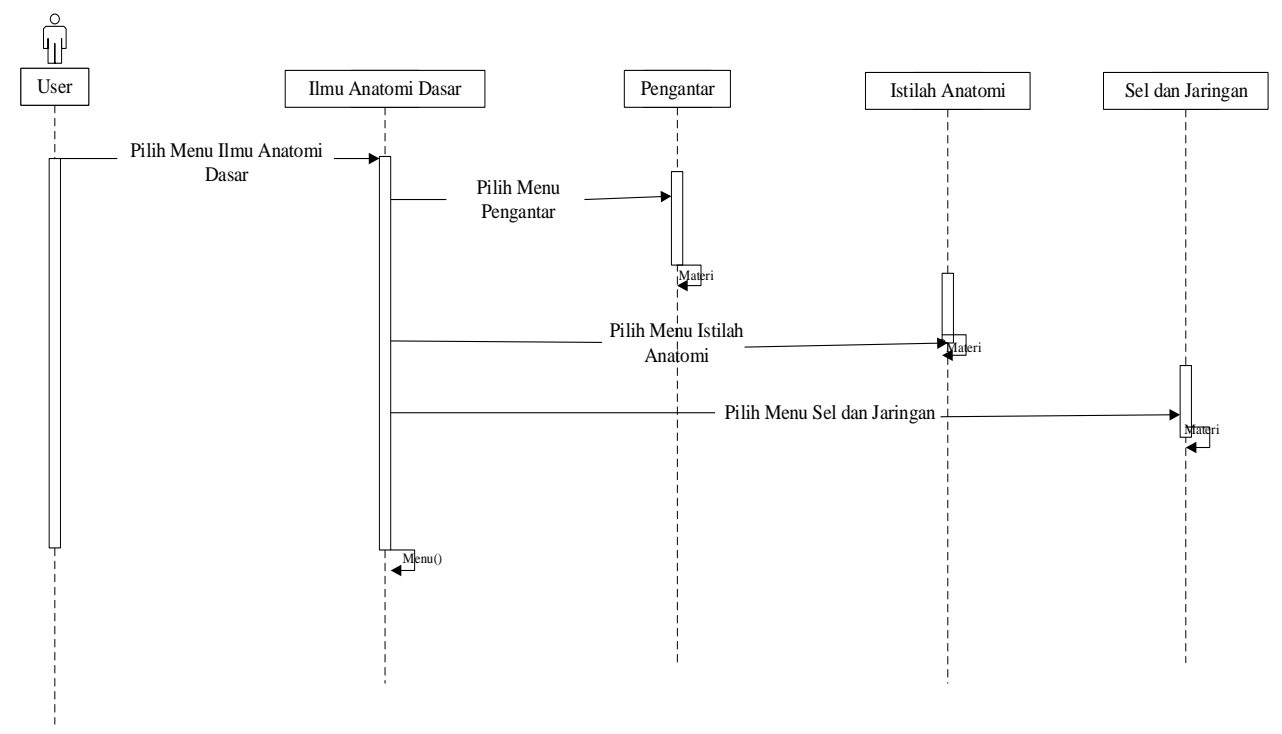

Gambar 2. Sequence Diagram Menu Ilmu Anatomi Dasar

Gambar 2. merupakan sequence diagram menu anatomi tubuh yang berisi materi dari setiap tombol. Adapun activity diagram halaman menu ilmu anatomi dasar terlihat pada Gambar 3. berikut.

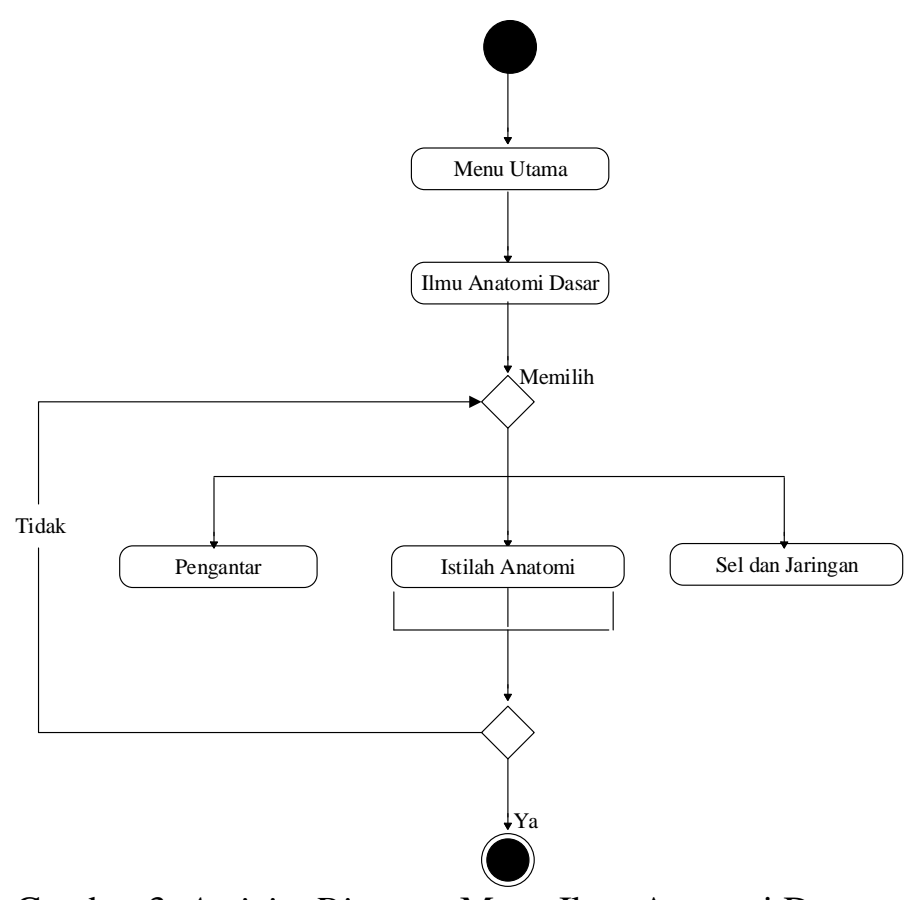

Gambar 3. Activity Diagram Menu Ilmu Anatomi Dasar

Gambar 3. User memilih menu ilmu anatomi dasar dan membuka menu materi pengantar, istilah anatomi, sel dan jaringan. Setelah selesai user akan kembali ke menu utama.

\subsection{Tampilan Hasil}

1. Tampilan Halaman Utama

Tampilan yang disajikan oleh sistem untuk menampilkan Halaman Utama aplikasi dapat dilihat pada Gambar 4. 


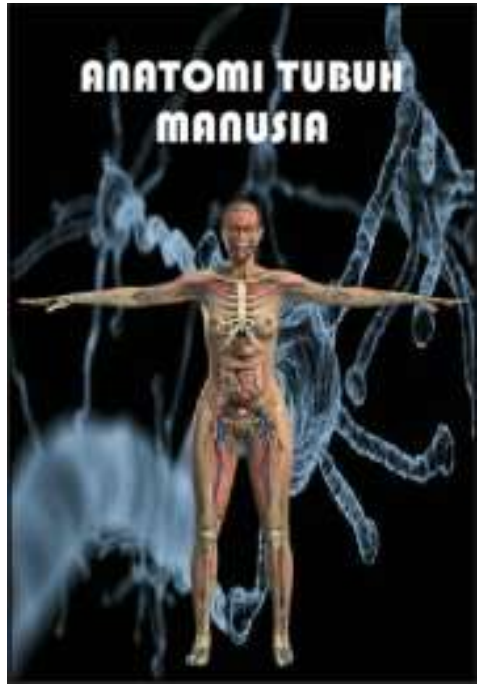

Gambar 4. Tampilan Halaman Utama

Pada tampilan awal aplikasi akan muncul pertama kali gambar pengenalan dari sistem aplikasi yang dijalankan, pengguna akan diarah kan ke halaman utama aplikasi setelah mengklik gambar tubuh manusia pada tampilan.

2. Tampilan Menu Utama Aplikasi

Tampilan yang disajikan oleh sistem untuk menampilkan menu utama aplikasi dapat dilihat pada Gambar 5.

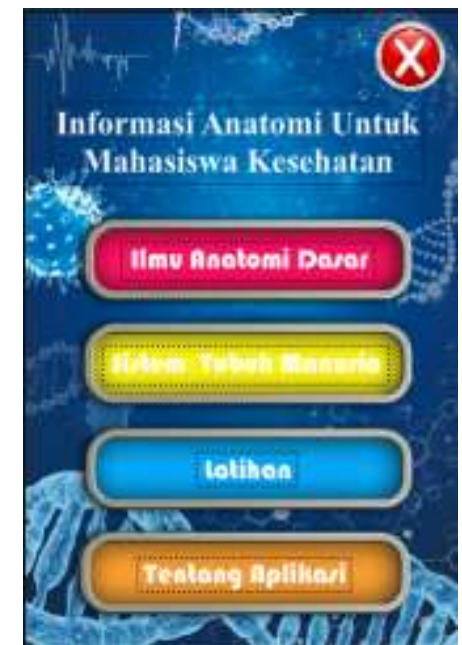

Gambar 5. Tampilan Menu Utama Aplikasi

Pada tampilan halaman utama aplikasi menampilkan beberapa menu seperti menu materi ilmu anatomi dasar dan menu materi sistem tubuh manusia. Lalu menu latihan dan menu tentang aplikasi.

3. Tampilan Menu Ilmu Anatomi Dasar

Tampilan yang disajikan oleh sistem untuk menampilkan halaman menu ilmu anatomi dasar pada aplikasi dapat dilihat pada Gambar 6. 


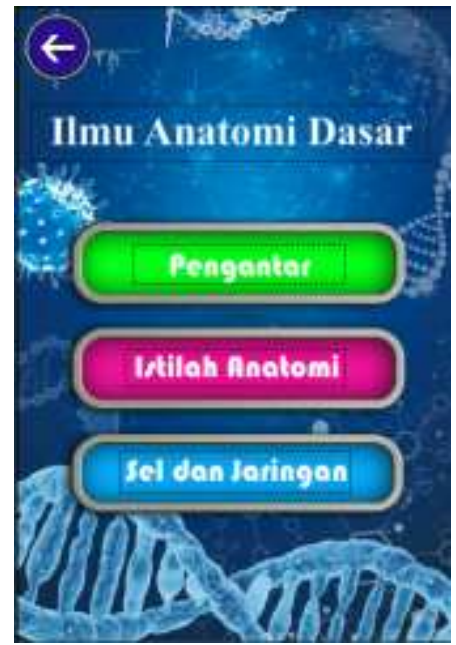

Gambar 6. Tampilan Menu Ilmu Anatomi Dasar

Pada tampilan menu ilmu dasar anatomi berisikan menu dengan materi awal untuk pengenalan anatami dasar, yang berisikan tombol pengantar yang menjelaskan materi pengenalan anatomi tubuh manusia, tombol istilah anatomi yang menjelaskan istilah awal dari anatomi tubuh manusia dan menu sel dan jaringan yang berisikan materi sel - sel dan jaringan yang ada pada tubuh manusia.

4. Tampilan Menu Sistem Tubuh Manusia

Tampilan yang disajikan oleh sistem untuk menampilkan halaman sistem tubuh manusia pada aplikasi dapat dilihat pada Gambar 7.

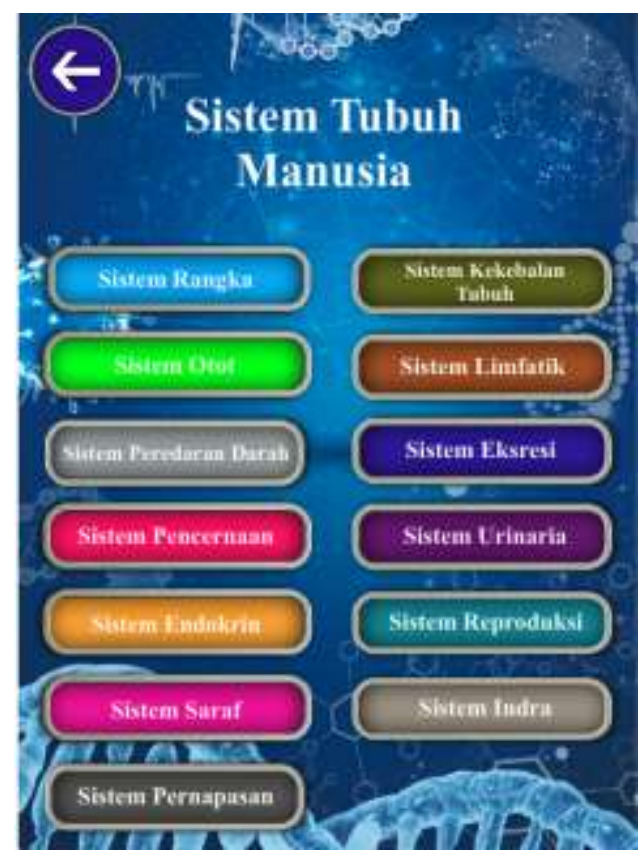

Gambar 7. Tampilan Menu Sistem Tubuh Manusia

Pada tampilan menu sistem tubuh manusia berisikan materi dari sistem - sistem tubuh, dimana terdapat fitur suara yang dapat membantu pengguna.

5. Tampilan Menu Latihan

Tampilan yang disajikan oleh sistem untuk menampilkan halaman menu latihan pada aplikasi dapat dilihat pada Gambar 8. 


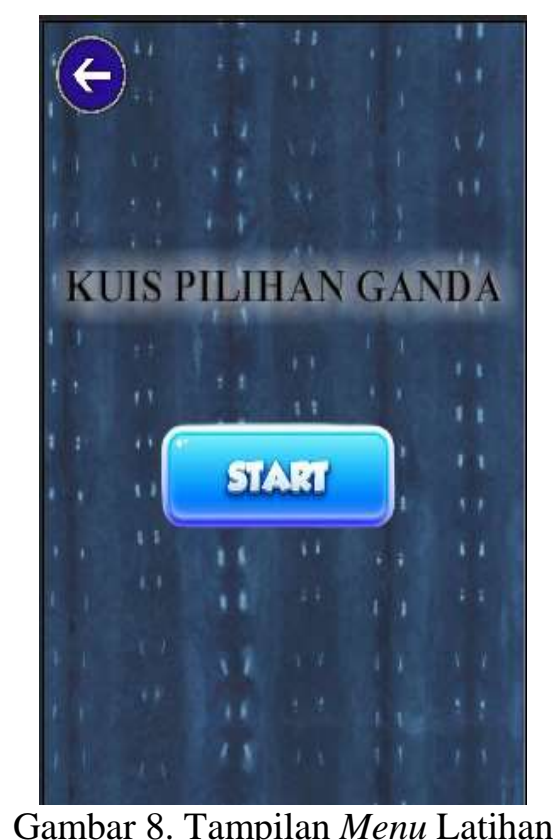

Pada Gambar 8 tampilan menu latihan, yang berisikan 20 soal tentang anatomi tubuh manusia.

6. Tampilan Menu Tentang Aplikasi

Tampilan yang disajikan oleh sistem untuk menampilkan halaman menu tentang aplikasi pada aplikasi dapat dilihat pada Gambar 9.

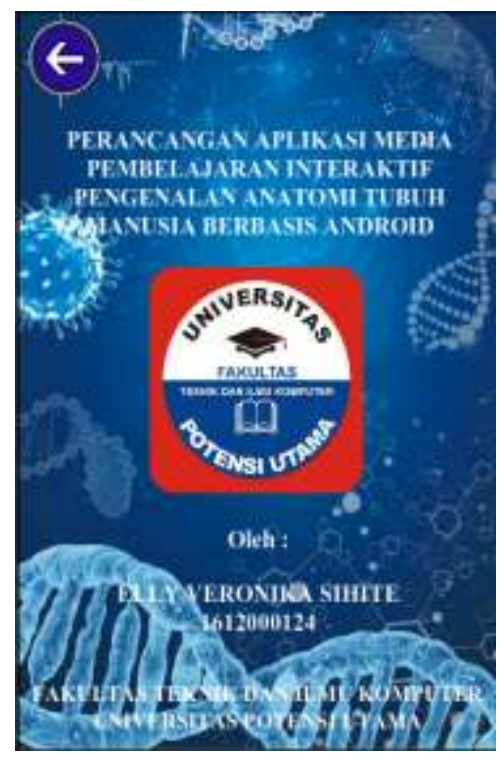

Gambar 9. Tampilan Menu Tentang Aplikasi

Pada tampilan menu tentang aplikasi merupakan tampilan data kreator.

\section{KESIMPULAN}

Berdasarkan proses perancangan, pembuatan dan pengujian media pembelajaran ini, dapat diambil beberapa kesimpulan sebagai berikut :

1. Materi dari media pembelajaran tentang pengenalan anatomi untuk mahasiswa kesehatan ini diisi berdasarkan buku dari Evelyn C. Pearce yang berjudul anatomi dan fisiologi untuk paramedic.

2. Aplikasi ini dapat berjalan dengan baik di semua versi android. 
3. Aplikasi ini dibuat dengan bahasa yang mudah untuk dipahami dan dapat bermanfaat bagi penggunanya.

\section{SARAN}

Berdasarkan proses perancangan, pembuatan dan pengujian media pembelajaran ini, dapat diambil beberapa saran sebagai berikut :

1. Menambahkan lebih banyak soal latihan untuk penambahan wawasan bagi mahasiswa kesehatan.

2. Penambahan suara dalam aplikasi untuk memudahkan mahasiswa mendengarkan penjelasan ketika tidak ingin membaca.

3. Membuat aplikasi untuk pengguna IOS, jadi tidak hanya dapat digunakan untuk pengguna android.

\section{DAFTARPUSTAKA}

[1] Nuniek Setyo Wardani, 2009, Analisis Dampak Penggunaan Perangkat Ajar Berbasis Multimedia, Fakultas Teknologi Informasi Universitas YARS

[2] Fitra, F., Nurhadi, N., \& Irawan, I. (2017). PERANCANGAN APLIKASI PERANGKAT AJAR PENGENALAN ANGGOTA TUBUH MANUSIA BERBASIS ANDROID. Jurnal Processor, 9(1), 89-97.

[3] Alfina, O., \& Harahap, F. (2019). PEMODELAN UML SISTEM PENDUKUNG KEPUTUSAN DALAM PENENTUAN KELAS SISWA SISWA TUNAGRAHITA. METHOMIKA: Jurnal Manajemen Informatika \& Komputerisasi Akuntansi, 3(2), 143-150.

[4] Khoiri, M. S., Tanti, L., \& Safrizal, S. (2018). Sistem Pendukung Keputusan Penerimaan Staff Pengajar Pada Yayasan Islamic Center Medan Dengan Penerapan Metode Profile Matching. Konferensi Nasional Sistem Informasi (KNSI) 2018.

[5] Setiawan, A. (2015). SISTEM PENDUKUNG KEPUTUSAN PENENTUAN ASISTEN PELATIH SEPAK BOLA MENGGUNAKAN METODE PROFILE MATCHING.

[6] Setiawan, A., \& Darma, S. (2013). Implementasi Decision Support System Dalam Penseleksian Calon Anggota Baru Badan Eksekutif Mahasiswa (BEM) dengan Metode GAP Kompetensi (Studi Kasus: Universitas Potensi Utama). SEMNASTEKNOMEDIA ONLINE, 3(1), 2-2.

[7] Haryanto, E. V., \& Nasari, F. (2017, November). Perbandingan Penerapan Metode Fuzzy Mamdani dan Sugeno Dalam Memprediksi Tingginya Pemakaian Listrik (Studi Kasus Kelurahan XYZ). In Seminar Nasional Informatika (SNIf) (Vol. 1, No. 1, pp. 534-539).

[8] Pairin, Y. B. (2018). Kode Autentikasi Hash pada Pesan Teks Berbasis Android. Jurnal Eksplora Informatika, 8(1), 6-14.

[9] Ikorasaki, F. (2018). PENERAPAN METODE ANP DALAM MELAKUKAN PENILAIAN KINERJA KEPALA BAGIAN PRODUKSI (STUDI KASUS: PT. MAS PUTIH BELITUNG). Jurnal Sistem Informasi Kaputama, 2(1).

[10] Iqbal, M. A., \& Rosnelly, R. (2020). PERANCANGAN APLIKASI MEDIA PEMBELAJARAN PENGENALAN LAPISAN BUMI MENGGUNAKAN AUGMENTED REALITY BERBASIS ANDROID. Jurnal Mahasiswa Fakultas Teknik dan Ilmu Komputer, 1(1), 927-940.

[11] Sianipar, J. A. P., \& Rosnelly, R. (2020). PERANCANGAN APLIKASI MEDIA PEMBELAJARAN HURUF DAN KOSAKATA HIRAGANA BAHASA JEPANG DENGAN AUDIO BERBASIS ANDROID. Jurnal Mahasiswa Fakultas Teknik dan Ilmu Komputer, 1(1), 899-914. 